\title{
RETINOPATHY IN HAEMOGLOBIN C TRAIT
}

\author{
M. HINGORANI ${ }^{1}$, C. R. BENTLEY ${ }^{2}$, H. JACKSON ${ }^{3}$, F. BETANCOURT ${ }^{1}$, R. ARYA ${ }^{4}$, \\ W. A. ACLIMANDOS ${ }^{3}$ and A. C. BIRD ${ }^{1}$ \\ London
}

\begin{abstract}
SUMMARY
Retinopathy associated with sickle-C and sickle cell disease is well described. Sickle trait and haemoglobin $C$ trait are generally considered benign conditions, with infrequent systemic manifestations. Rare cases of retinopathy in sickle trait, in the presence of contributory factors, exist and we recently reported three such patients. The occurrence of retinopathy in haemoglobin $C$ trait is even less well documented. Haemoglobin $C$ does not cause red blood cell sickling but is known to decrease erythrocyte plasticity and increase blood viscosity. We report three cases in which haemoglobin C trait was associated with significant peripheral vascular occlusion and seafan formation (confirmed by fluorescein angiography) similar to that seen in sickle retinopathy. Two patients had coexistent systemic disease (hypertension and diabetes mellitus). Vitreous haemorrhage was the presenting feature in two patients. It is evident that haemoglobin $C$ trait may be associated with sight-threatening complications.
\end{abstract}

Homozygous sickle cell haemoglobinopathy (SS) and sickle-C (SC) disease are a significant cause of both ocular and systemic morbidity. ${ }^{1}$ SS disease is associated with more serious systemic complications than SC disease and yet visual loss due to proliferative retinopathy is more common in SC disease for reasons that are uncertain. ${ }^{1-4}$ Homozygous haemoglobin $(\mathrm{Hb}) \mathrm{C}$ disease is mild and no ocular associations have been reported. ${ }^{1,5}$

The heterozygous states are more common. Sickle trait (AS) is found in 9\% of North American AfroCaribbeans and $\mathrm{HbC}$ trait $(\mathrm{AC})$ in $2 \%$ of this population. ${ }^{4}$ Sickle trait is traditionally considered a benign disorder, particularly in terms of ocular

\footnotetext{
From: ${ }^{1}$ Professorial Unit, Moorfields Eye Hospital, London; ${ }^{2}$ Department of Neuro-Ophthalmology, National Hospital for Neurology and Neurosurgery, London; ${ }^{3}$ Department of Ophthalmology, King's College Hospital, London; ${ }^{4}$ Department of Haematology, King's College Hospital, London, UK.

Correspondence to: Mrs M. Hingorani, Clinical Fellow, Professorial Unit, Moorfields Eye Hospital, City Road, London EC1V 2PD, UK. Tel: +44 (171) 253 3411. Fax: +44 (171) 251 9350.
}

involvement, ${ }^{6,7}$ although we have recently reported a series of patients who exhibited a proliferative retinopathy with haemoglobin AS in association with other possible predisposing factors. ${ }^{8}$ We now report three patients with $\mathrm{HbC}$ trait who developed a retinopathy resembling that seen in sickle cell disease.

\section{CASE REPORTS}

\section{Case 1}

A 33-year-old non-insulin-dependent diabetic and hypertensive man from Barbados was referred with suspected proliferative diabetic retinopathy. Diabetes had been diagnosed 5 years previously and his medication was lisinopril and metformin which gave good diabetic and blood pressure control. There was a family history of sickle cell disease. The visual acuities were $6 / 5$ right and 6/6 left and anterior segment examination and intraocular pressures were normal. Fundoscopy showed sparse scattered microaneurysms and areas of peripheral seafan neovascularisation (Fig. 1). Fluorescein angiography (Fig. 2) confirmed the presence of microaneurysms at the posterior pole and demonstrated severe bilateral peripheral vascular closure with multiple, leaking seafans. He was shown to have $\mathrm{HbC}$ trait on electrophoresis with a negative sickling test.

\section{Case 2}

A 43-year-old Jamaican man complained of a sudden blurring of vision in the right eye with floaters. The left vision had been poor since childhood following blunt trauma. He was fit and well and there was no family history of sickle cell disease. The corrected visual acuity was 6/36 right and 6/12 left with normal anterior segment and tonometric examinations. There was a moderate degree of right vitreous haemorrhage obscuring the retinal view and in the left eye the only abnormal finding was an epiretinal membrane involving the macula.

The haemorrhage resolved to reveal non-perfusion of the retina anterior to the temporal equator with 


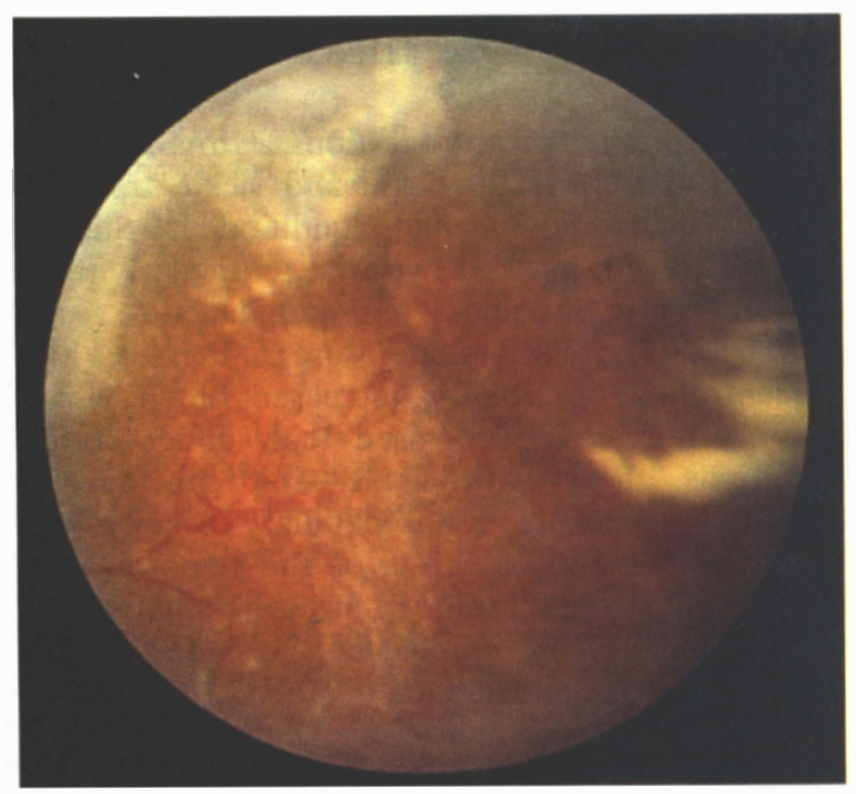

Fig. 1. Case 1. Peripheral seafan neovascularisation.

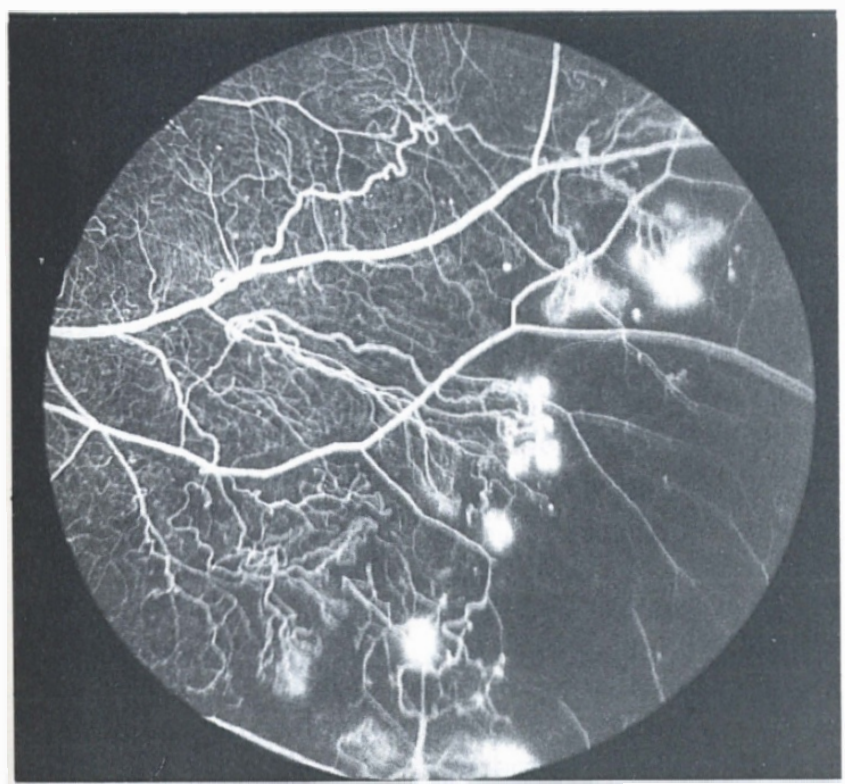

Fig. 2. Case 1. Fluorescein angiography shows peripheral capillary closure and leakage from seafans.

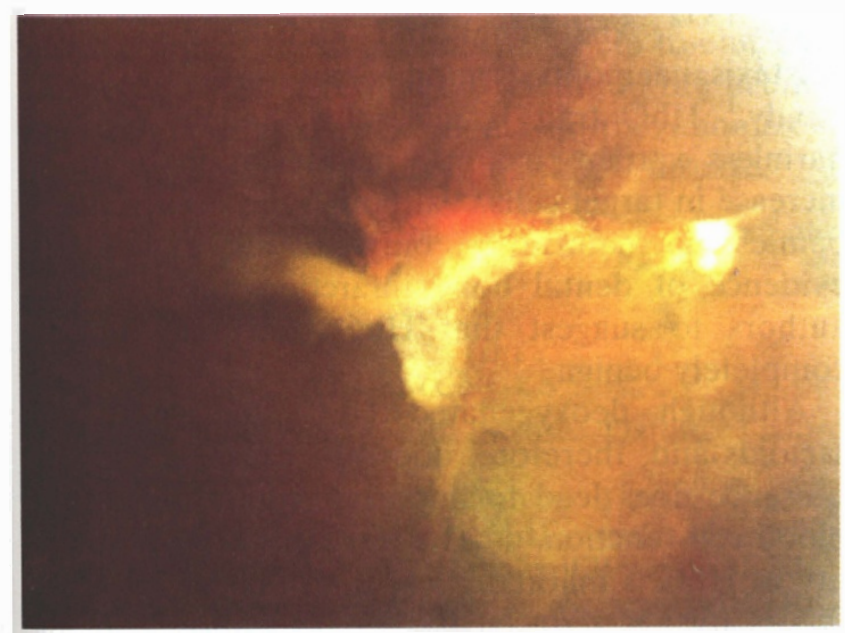

Fig. 3. Case 2. Fundal photography shows a large, partly fibrosed seafan surrounded by a small tractional retinal detachment.

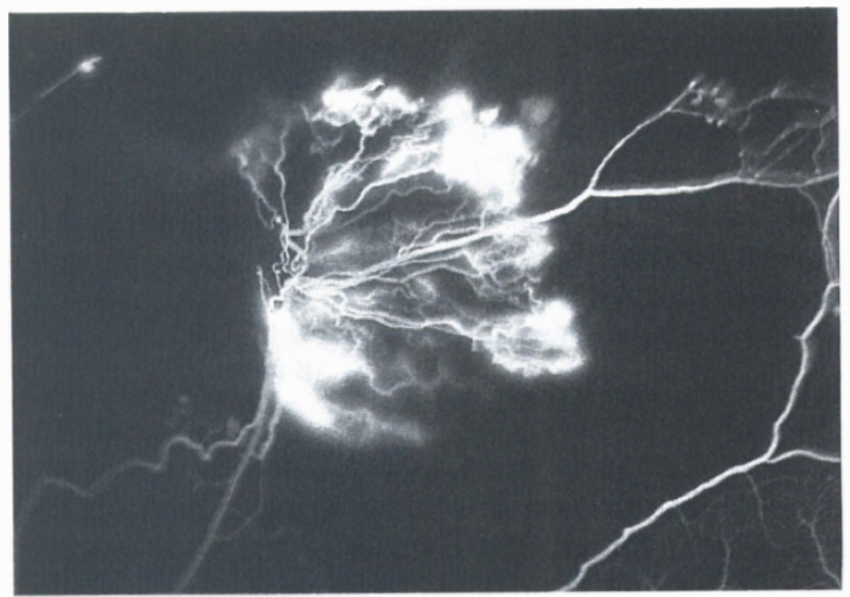

Fig. 4. Case 2. Fluorescein angiogram in the right eye reveals several leaking seafans with marked peripheral vascular occlusion.

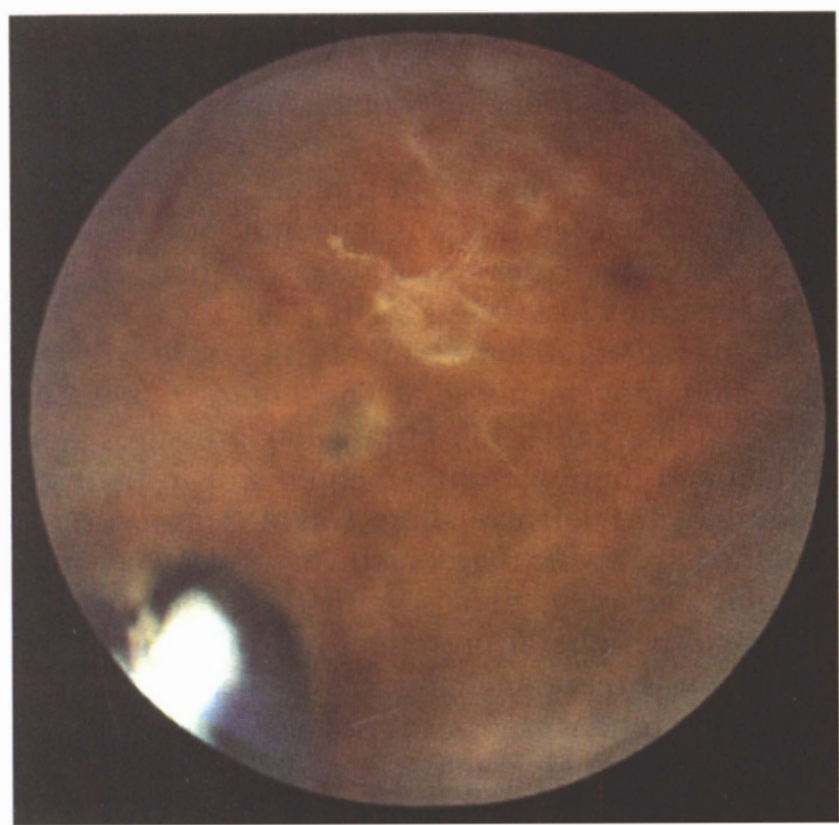

Fig. 5. Case 3. In the left eye the fundus photograph demonstrates preretinal fibrosis.

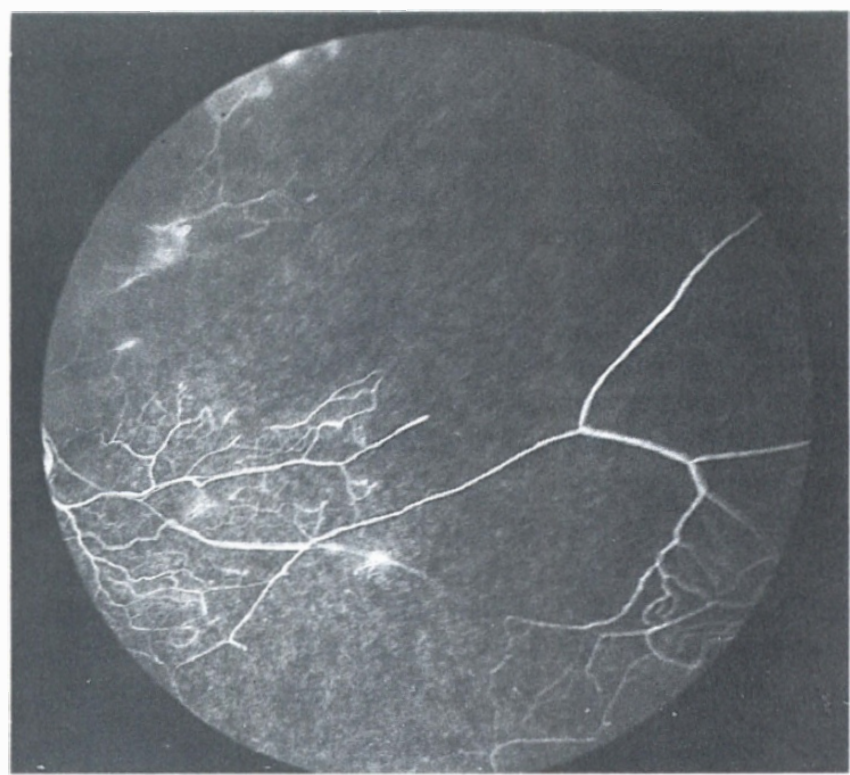

Fig. 6. Case 3. An area of seafan is shown leaking dye on fluorescein angiography. 
scattered small black sunbursts and foci of preretinal fibrous tissue (Fig. 3). In the superotemporal quadrant, an area of seafan neovascularisation projected into the vitreous and was surrounded by a small tractional retinal detachment.

Fluorescein angiography in the right eye revealed peripheral retinal vessel closure with arteriovenous shunts and profuse dye leakage from the superotemporal seafan (Fig. 4). After 5 months, the right vision had improved to 6/12, with no change in the retinal detachment and fibrosis of the new vessels. Systemic examination failed to show any abnormality and the blood pressure was normal. Hb electrophoresis showed $\mathrm{HbC}$ trait with a negative sickling test.

\section{Case 3}

A 32-year-old Ghanaian woman presented with a sudden reduction of vision and photopsia in the left eye. There was no history of trauma, she was known to be hypertensive but was currently not on treatment and denied sickle cell disease. There was no relevant family history.

On examination, her visual acuities were $6 / 6$ right and hand movements left. The anterior segments were unremarkable, the intraocular pressures were normal and there was a pigmented scar in the right fundus. In the left eye there was a dense vitreous haemorrhage which resolved to reveal a large atrophic and pigmented scar in the posterior pole and some peripheral preretinal fibrosis (Fig. 5). At no stage was there any clinical evidence of reactivation of the retinal scar or intraocular inflammation.

Fluorescein angiography (Fig. 6) revealed peripheral capillary occlusion with an area of seafan neovascularisation superotemporally. Haemoglobin electrophoresis revealed $\mathrm{HbC}$ trait with a negative sickling test.

\section{DISCUSSION}

Retinopathy characterised by vascular occlusion, neovascularisation and haemorrhage has been reported in a variety of haemoglobinopathies, most commonly in SS and SC disease. ${ }^{7.9}$ Haemoglobins S and $\mathrm{C}$ arise by single amino acid substitutions: glutamic acid at position 6 on the normal $\mathrm{HbA} \beta$ chain is replaced by valine in $\mathrm{HbS}$ and lysine in $\mathrm{HbC} .{ }^{10}$ Under conditions of low oxygen tension, $\mathrm{HbS}$ aggregates to form tactoids (liquid crystals) which deform the erythrocyte cell membrane to produce the characteristic sickle shape. ${ }^{11,12}$ Sickled red cells are less deformable and increase blood viscosity, leading to occlusion of capillaries, local ischaemia and further sickling, ${ }^{11,12}$ and the rapid destruction of abnormal erythrocytes produces a haemolytic anaemia. ${ }^{1}$ Intravascular sickling has been believed to underlie all the clinical manifestations of sickle cell anaemia. ${ }^{11}$
Under physiological conditions, HbAS erythrocytes do not normally sickle and sickle trait was initially considered a benign condition. ${ }^{13,14}$ Sickling may occur with marked hypoxia, particularly if the oxygen affinity of haemoglobin is reduced (e.g. low $\mathrm{pH}$, high $\mathrm{pCO}_{2}$, raised temperature), if there is a high concentration of $\mathrm{HbS}$ or increased blood viscosity. ${ }^{12.15}$ It is now recognised that, under certain conditions, those with sickle trait can develop haemolytic anaemia, renal papillary necrosis and haematuria, aseptic necrosis of the femoral head, splenic infarction, thrombosis of intracranial venous sinuses, pulmonary embolism, mesenteric artery occlusion, stroke and sudden death. ${ }^{1.16-19}$

Serious ocular complications of sickle trait are unusual, but have been described. Central retinal artery occlusion has been reported, not only in association with serious systemic disease or blunt ocular trauma but also without an obvious precipitating cause. ${ }^{20-25}$ Secondary glaucoma, possibly due to the trapping of sickled erythrocytes in aqueous outflow channels, has been described following traumatic hyphaema. ${ }^{26-28} \mathrm{Nagpal}$ et al. ${ }^{29}$ described seven patients with sickle trait and vasoproliferative retinopathy, but in all there was some evidence of systemic disease such as sarcoid, diabetes, tuberculosis and syphilis. They suggested these systemic disorders created unfavourable conditions which led to enhanced sickling, and this was supported by other reports of typical sickle retinopathy in the presence of hypertension and diabetes. ${ }^{8.30}$ It appears, however, that such retinopathy can occur without any other obvious precipitating cause. ${ }^{31.32}$ It may be that retinopathy in sickle trait is not as uncommon as usually thought. Welch and Goldberg ${ }^{32}$ found $27 \%$ of $\mathrm{HbAS}$ patients to show retinal change characteristic of sickle retinopathy.

Homozygous $\mathrm{HbC}$ disease may be associated with moderate haemolytic anaemia, splenomegaly and abnormal numbers of target cells and microspherocytes. $^{1.5 .12}$ Abdominal and joint pain, seizures, epistaxis, haemoptysis and haematuria occur uncommonly.' $\mathrm{HbC}$ trait is generally thought to be a harmless variant, its only manifestation being an increase in target cells, ${ }^{33}$ although the occurrence of painless haematuria, osteomyelitis and radiological evidence of dental bone infarction has led some authors to suggest that $\mathrm{HbC}$ trait may not be completely benign. ${ }^{1,4,34}$

Although deoxygenated $\mathrm{HbC}$ does not form tactoids and, therefore, does not cause sickling, its presence does lead to important alterations in red blood cell function. ${ }^{1.33}$ The intra-erythrocyte solubility of $\mathrm{HbC}$ is markedly less than that of $\mathrm{HbA}$ and this is further reduced by deoxygenation. ${ }^{35}$ In the homozygous state, tetragonal crystalloid inclusions of $\mathrm{HbC}$ are seen in some red cells, and with osmotic 
dehydration crystal formation occurs in virtually all the cells. ${ }^{1,12,35,36} \mathrm{HbCC}$ and $\mathrm{HbAC}$ erythrocytes exhibit decreased plasticity and increase blood viscosity, proportional to the percentage of $\mathrm{HbC},{ }^{12,35}$ which may be due to the existence of haemoglobin in a poorly soluble 'precrystalline state'. 35

It is conceivable that such rigid erythrocytes could occlude retinal capillaries and lead to a sickle-like ischaemic retinopathy without the requirement for sickling, particularly in the presence of other vasculopathies such as diabetes and hypertension, which coexisted in two of our cases. This suggestion is supported by previous observations. Moschandreou et $a l .{ }^{37}$ reported typical sickle retinopathy in three cases of $\mathrm{HbAC}$, two with seafan neovascularisation. One of these patients was hypertensive but the other two were apparently healthy. Of nine healthy AC patients screened by Welch and Goldberg $^{32}$ three exhibited retinal vascular changes (venous tortuosity, chorioretinal scars and obliteration of peripheral blood vessels) but no proliferative disease. It may be, then, that retinopathy is more common than previously thought in $\mathrm{HbC}$ trait. Alternatively, patients with AC and retinopathy may have additional risk factors. The effect of interactions between coexistent variants of haemoglobin on the clinical manifestations of haemoglobinopathy is well recognised. ${ }^{11,12}$ The reasons for more severe retinopathy but milder systemic disease in $\mathrm{HbSC}$ than in $\mathrm{HbSS}$ are not yet fully understood, ${ }^{2,3,7}$ but perhaps interhaemoglobin interactions are of particular importance in microcirculatory disorders such as retinal vasculopathy. In patients with $\mathrm{HbAC}$ and retinopathy there may be interactions between $\mathrm{HbC}$ and an abnormal haemoglobin indistinguishable electrophoretically from $\mathrm{HbA}$ which have yet to be recognised.

It appears that fundal changes characteristic of sickle retinopathy may occur in haemoglobinopathies in which frank sickling is not a feature. Further investigation of these patients may help to elucidate the mechanisms of retinal disease in all the haemoglobinopathies and to account for the anomalous severity of ocular pathology in sickle-C disease.

Key words: Haemoglobin C, Haemoglobinopathy, Retinopathy, Sickle trait.

\section{REFERENCES}

1. Serjeant GR. Sickle cell disease. Oxford: Oxford University Press, 1992.

2. Penman AD, Talbot JF, Chuang EL, et al. New classification of peripheral retinal vascular changes in sickle cell disease. Br J Ophthalmol 1994;78:681-9.

3. Fox PD, Dunn DT, Morris JS, Serjeant GR. Risk factors for proliferative sickle retinopathy. $\mathrm{Br} \mathrm{J}$ Ophthalmol 1990;74:172-6.

4. Myerson RM, Harrison E, Lohmuller HW. Incidence and significance of abnormal haemoglobins. Am J Med 1959;26:543-6.

5. Hartz WH, Schwartz SO. Hemoglobin C disease. Blood 1955;10:235-46.

6. Lieb WA, Geeraets WJ, Guerry D. Sickle cell retinopathy: ocular and systemic manifestations of sickle cell disease. Acta Ophthalmol (Copenh) 1959;37(Suppl 58):7-45.

7. Goldberg MF. Retinal neovascularisation in sickle cell retinopathy. Trans Am Acad Ophthalmol Otolaryngol 1977;83:409-31.

8. Jackson H, Bentley CR, Hingorani M, et al. Sickle retinopathy in patients with sickle trait. Eye 1995;9:589-93.

9. Condon PI, Serjeant GR. Behaviour of untreated proliferative sickle retinopathy. $\mathrm{Br} \mathrm{J}$ Ophthalmol 1980;64:404-11.

10. Stamatoyannopoulos G. The molecular basis of hemoglobin disease. Annu Rev Genet 1972;6:47-70.

11. Conley CL. Pathophysiological effects of some abnormal hemoglobins. Medicine 1964;43:785-7.

12. Conley CL, Charache S. Mechanisms by which some abnormal hemoglobins produce clinical manifestations. Semin Hematol 1967;4:53-71.

13. Chernoff A. The human hemoglobins in health and disease. N Engl J Med 1955;253:322-31, 365-74.

14. Itano HA. Clinical states associated with alterations of the hemoglobin molecule. Arch Intern Med 1955; 96:287-97.

15. Dean J, Schechler AN. Sickle cell anaemia: molecular and cellular basis of therapeutic approaches. N Engl J Med 1978;299:753, 804-11, 863-70.

16. Chapman AZ, Reeder PS, Friedman IA, et al. Gross hematuria in sickle cell trait and sickle cell hemoglobinC disease. Am J Med 1955;19:773-82.

17. Rotter R, Luttgens WF, Peterson WL, et al. Splenic infarction in sicklemia during airplane flight: pathogenesis, hemoglobin analysis and clinical features of six cases. Ann Intern Med 1956;44:257-70.

18. Chazan AA, McSorley JGA. Haemolytic anaemia in sickle-cell trait. BMJ 1956;2:283-4.

19. Ratcliff RG, Wolf MD. Avascular necrosis of the femoral head associated with sickle cell trait (AS hemoglobin). Ann Intern Med 1962;57:299-304.

20. Kabakow B, Van Weimokly SS, Lyons HA. Bilateral central retinal artery occlusion. Arch Ophthalmol 1955;54:670-6.

21. Stein MD, Gay AJ. Acute chorioretinal infarction in sickle cell trait. Arch Ophthalmol 1970;84:485-90.

22. Conrad WC, Penner R. Sickle-cell trait and central retinal artery occlusion. Am J Ophthalmol 1967; 63:465-8.

23. Michaelson PE, Pfeffenbach D. Retinal arterial occlusion following ocular trauma in youths with sickle-trait hemoglobinopathy. Am J Ophthalmol 1972;74:494-7.

24. Sorr EM, Goldberg RE. Traumatic central retinal artery occlusion with sickle cell trait. Am J Ophthalmol 1975;80:648-52.

25. Radius RL, Finkelstein D. Central retinal artery occlusion (reversible) in sickle trait with glaucoma. $\mathrm{Br}$ J Ophthalmol 1976;60:428-30.

26. Goldberg MF. The diagnosis and treatment of secondary glaucoma after hyphaema in sickle cell patients. Am J Ophthalmol 1979;87:43-9.

27. Friedman $\mathrm{AH}$, Halpern BL, Friedberg DN, et al. Transient open-angle glaucoma associated with sickle cell trait: report of four cases. $\mathrm{Br} \mathrm{J}$ Ophthalmol 1979;63:832-6.

28. Wax MB, Ridley ME, Margargal LE. Reversal of 
retinal and optic disc ischaemia in a patient with sickle cell trait and glaucoma secondary to traumatic hyphaema. Ophthalmology 1982;89:845-51.

29. Nagpal KC, Asdourian GK, Patrianakos D, et al. Proliferative retinopathy in sickle cell trait. Arch Intern Med 1977;167:325-8.

30. Dowhan TP, Bodnar ME, Daniels MB. Optociliary shunts and sickle retinopathy in a woman with sickle cell trait. Ann Ophthalmol 1990;22:66-9.

31. Isbey EK, Clifford GO, Tanaka KR. Vitreous haemorrhage associated with sickle-cell trait and sickle cell hemoglobin-C disease. Am J Ophthalmol 1958;45: 870-9.

32. Welch RB, Goldberg MF. Sickle-cell hemoglobin and its relation to fundus abnormality. Arch Ophthalmol 1966;75:353-62.

33. Kaplan E, Zuelzer WW, Neel JV. Further studies on hemoglobin C. Blood 1953;8:735-46.
34. Prowler JR, Smith EW. Dental changes occurring in sickle cell diseases and abnormal hemoglobin traits. Radiology 1955;65:762-8.

35. Charache S, Conley CL, Waugh DF, et al. Pathogenesis of hemolytic anaemia in homozygous hemoglobin $\mathrm{C}$ disease. J Clin Invest 1967;46:1795-811.

36. Diggs LW, Kraus AP, Morrison DB, Rudniki RPT. Intraerythrocytic crystals in a white patient with hemoglobin $\mathrm{C}$ in the absence of other types of hemoglobins. Blood 1954;9:1172-84.

37. Moschandreou M, Galinos S, Valenzuela R, et al. Retinopathy in hemoglobin C trait (AC hemoglobinopathy). Am J Ophthalmol 1974;77:465-71.

38. Van Meurs JC. Relationship between peripheral vascular closure and proliferative retinopathy in sickle cell disease. Graefes Arch Clin Exp Ophthalmol 1991;229:543-8. 